Abstracta Iranica Iranica

Revue bibliographique pour le domaine irano-aryen

Volume 29 | 2008

Comptes rendus des publications de 2006

\title{
Jean de Dalyatha, les Homélies I-XV. Antélias, 2006. (Sources syriaques, 2)
}

\section{Florence Jullien}

\section{(2) OpenEdition \\ 1 Journals}

Édition électronique

URL : http://journals.openedition.org/abstractairanica/29912

DOI : 10.4000/abstractairanica.29912

ISSN : 1961-960X

\section{Éditeur :}

CNRS (UMR 7528 Mondes iraniens et indiens), Éditions de l'IFRI

\section{Édition imprimée}

Date de publication : 15 mai 2008

ISSN : 0240-8910

\section{Référence électronique}

Florence Jullien, « Jean de Dalyatha, les Homélies I-XV. Antélias, 2006. (Sources syriaques, 2) », Abstracta Iranica [En ligne], Volume 29 | 2008, document 271, mis en ligne le 15 septembre 2008, consulté le 25 septembre 2020. URL : http://journals.openedition.org/abstractairanica/29912 ; DOI : https://doi.org/10.4000/abstractairanica.29912

Ce document a été généré automatiquement le 25 septembre 2020.

Tous droits réservés 


\section{Jean de Dalyatha, les Homélies I-XV. Antélias, 2006. (Sources syriaques,} 2)

Florence Jullien

1 Ce travail est une contribution importante à notre connaissance de la mystique syroorientale dont Jean de Dalyatha est une figure de premier plan. La traduction du syriaque est très rigoureuse et attentive à restituer la richesse de la pensée de ce moine $\mathrm{du} \mathrm{VIII}^{\mathrm{e}} \mathrm{s}$. Intéressant est le pont établi entre les écrits de Jean de D. et l'accueil très favorable qu'en fit la communauté syro-orthodoxe. Une série d'indices commode est assortie d'un index des thèmes importants ; ce petit glossaire offre au lecteur un véritable parcours synthétique de la pensée de Jean de Dalyatha à travers ses Homélies.

\section{INDEX}

Thèmes : 6.3. Autres religions

\section{AUTEURS}

FLORENCE JULLIEN

EPHE - Paris 